\title{
RESPONSE
}

\section{An Interview with Nils Christie}

Luc Robert

\section{INTRODUCTION}

Nils Christie is a professor of Criminology at the Faculty of Law at the University of Oslo in Norway and is the author of a number of books, notably Crime Control as Industry. ${ }^{1}$ He was recently a member of the U.S. National Criminal Justice Commission, created to conduct a comprehensive assessment of crime policy in America. ${ }^{2}$ The NCJC addressed such critical issues as the political currency of fear of crime, the rise of the new prisonindustrial complex, and the war on drugs-issues that reflect Christie's concern with the growing development of a crime control industry.

In late October, 2000, Nils Christie was in Vancouver, British Columbia to speak at a conference sponsored by the Centre for Restorative Justice at the School of Criminology, Simon Fraser University. He was interviewed on October 28 by Luc Robert. The transcript of this one-hour discussion has been edited.

Robert: In these days, with ever-increasing attention on victims of crime, with the co-optation of restorative justice by the retributive system, ${ }^{3}$ with victim advocates who demand harsher punishments and with the wars against drugs and crime, the prison system seems to be the only serious reaction to crime. Judges, public prosecutors, politicians and the media hardly ever talk about prison as "the last resort;" for most of them it is the only answer to crime.

$1 \quad$ First published in 1993 (New York: Routledge). In this book, Christie argues that crime control, rather than crime, is the real danger for the future.

2 From the Report of the National Criminal Justice Commission, The Real War on Crime. Edited by Steven R. Donziger (New York: Harper Perennial, 1996).

3 Restorative justice is often treated as a "program" within the existing justice system, rather than a guiding philosophy by which to transform current practices. 
Christie: Yes, prison seems to be used as the first resort to crime. There are several things going on at the same time. First of all is that the penal law system in a way is a self-initiating system. It grows because of its own size and it grows because of forces inside the system - people who want a job, people, as for example, the Californian prison organization that gives money to both political parties. This is the whole crime industry concept. As you know, in that book I take a parallel in some way to Zygmunt Bauman's book on the Holocaust. There are no "bad" people, but the system together creates this situation. But in addition comes, of course, as a new element, that politicians these days show a much greater interest in penal matters. And I think it is related to the phenomenon that politicians do not have so many areas where they can expose their values, so the penal arena is a suitable one in which to wave the flag, to show who they are and what they want to do.

Robert: This is what Thomas Mathiesen calls the politicization of penal policy.

Christie: Yes, and it is in a way a very dangerous phenomenon. I recently met the new chairman of the Committee for Legal Matters in Norway. She had earlier been on another committee and she said that to go from that old committee to this new one where penal matters were central, that was to come out of the valley of shadows into the clear sunshine. Never were there any questions for her in her former capacity, but now, in this new committee, every day was filled with questions from the media on her opinions on these matters. So, it is a sort of glorious place for a politician to profile herself in this arena. This is a very strong tendency, and I think you can also see it in some of the phenomena exposed in the U.S., such as the chain gangs and also these attempts to make the prisons look ugly - "there should be suffering there, no coffee in my prison." For a sort of modern bureaucratic process, it has some element of emotional outbursts.

This is very interesting and I think I have not covered that sufficiently in my latest book. But I have just read a manuscript this morning by John Pratt from New Zealand that underlines this phenomenon, that on the one hand you have the prison system, administered by the prison staff, going its usual way, but filling up more and more. And then you have the politicians. Then you have the popular attitudes of anger and concern, particularly directed these days towards the paedophiles. But then, on the other hand, you have restorative justice. Emotions can be bad, in the way of "kill them!" but emotions might also be very good-"let us meet them," "let us restore the 
conditions"-so the picture is not so completely clear. It will be interesting to see if the restorative justice response will be dominant or if the sort of "kill them, castrate them" response will be dominant. In a way, Pratt's manuscript opened my eyes to this interesting two-track development.

Robert: And in light of all this, how do you see the future of prison and imprisonment?

Christie: It is so difficult to predict the future. I want to mention one very encouraging tendency from Russia. It seems as if they, in a way, keep control of the system now, interestingly enough. They might be able to do it because it is a centralized system, so when they really see the light - that this is a very expensive system, with lots of negative elements - then they might be able to control that development. But in systems that are not so strictly centralized, it is very difficult to control the figures when they go up and to force them to go down. So very much will depend in the U.S. on the economy, of course, and very much on when imprisonment will be perceived as too expensive. But it is not necessarily so bad for a state such as the U.S. to have a large prison population, from an economic point of view. It is a sort of buffer. Their state work, or the public sector, is the prison sector for them, which is seen as some sort of necessity. But it is a good thing for those working there; it is a good thing if you want to control the underclass with punitive means.

And then we come to the question: when will it be too expensive and when will it be so enormous that they will also take some of the middle class or some of the politically more influential people into the prison, or their kids, or their relatives? They will have to find a balance. There are some small indicators now that the growth of the prisons in the U.S. is slowing down, but not very much. And still, the growth is extraordinary. Europe has also had growth. The most interesting case here is the Netherlands, which was the prime example of liberalism and suddenly found its way to the "normal" European figures. It has, of course, nothing to do with crime; it has to do with crime control.

Robert: As one of the advocates of restorative justice, I would like to ask you the following question: do you think restorative justice can work in prison (in a post-sentencing phase)? What would be the best approach there?

Christie: First of all, the most important approach is to try to prevent imprisonment. So what happens before prison is the most important thing. 
But what happens when inside the prison? It depends a lot on the sophistication in the thinking around it. If this is seen as a sort of new way of classifying prisoners, those who are willing to regret what they did and those who are not willing to regret it, then we might put more power in the hands of the authorities. That sounds like a dangerous road to go down. It is a dangerous way because it might lead to so much hypocrisy and very unpleasant situations. So, one could hope that prisoners would have nothing to gain in time spent in prison, but they might gain something in a real meeting between humans. It should be a real meeting where the victim gets some keys and answers to his or her questions and the offender gets a chance to tell how sorry he is and try to convince the other person that he is not a monster. It might be a very important part of the process, but as I said, that he should be released earlier because of that is a situation that we at least have to think through.

Of course, in the other restorative justice processes, it is somewhat the same problem: the accused will know that if he is unhappy, very sorry about what he did and asks for forgiveness, maybe he escapes prison. So the sincerity of the process may be doubted in that case. I have no clear view of this problem. What is your view on this problem?

Robert: I think, likewise, as soon as a prisoner believes that he can get a reduction of his sentence (an early release) when going into a restorative process, it is not good. It opens the door to hypocrisy. The prisoners have to do it for themselves and for the victims.

Christie: Yes, that is my idea too.

Robert: If offenders participate in a restorative justice process in the postsentencing phase, they should not get any advantage from it in terms of a reduction of their sentence. Another question then: what about those who volunteer to participate in a restorative justice process, but who get a negative response from the victim, as well as the other way around (the victim volunteers, but the accused doesn't)?

Christie: There can't be anything done. I understand both the victim and the offender. If I were to do something terrible to you, I don't think I would have the courage to meet you, but I hope I would have. And we can try, by being ordinary decent human beings, to tell the victim that it would be good for him or her to meet the offender. But you can, of course, never force anyone to participate in a restorative process. 
Robert: Yesterday you talked about the minimalist approach to punishment and the abolitionist approach. ${ }^{4}$ Is it really an achievable goal, to go to a minimal approach to justice?

Christie: It depends. First of all, I split the approaches into three positions: the abolitionist, the minimalist, and the maximalist. To me, it is the maximalist approach to punishment that rules the field today. I think we should use all our efforts to stop that wild move towards the maximalist position. It is very much to try to rescue civil society, to convert as much as possible into civil conflicts. I think that is essential. But then, when it comes down to the question of the minimalist or the abolitionist position, I think that it is not necessary for them to have any fights. Both of them are minority positions, so it is much better to focus on stopping this terrible growth. [The Dutch academic] Louk Hulsman is an abolitionist and a good friend of mine, and we have no opposition. I doubt, if he was pressed, that he would choose to drop the whole penal law procedure. And you would see that there are certain values, exactly for cases where the victim does not want to meet the offender or the offender does not want to meet the victim. It is sort of a relief to me to look at that minimal position, that minimum of penal law as a sort of safety valve in the system.

Robert: Won't you face the vested interests of the professionals in the field of corrections?

Christie: I am not so sure. First of all, you should be aware of a great change that has taken place within many systems of corrections, at least in our small countries. When I compare the correctional officers today with those I met fifty years ago it can hardly be compared, I think partly due to the many women who are now moving into the service. I think more than half of the people at our prison schools are women today. It has changed the atmosphere. Many are able to cope with this double purpose: see to it that prisoners do not escape, but also to be decent human beings vis-à-vis the prisoners. I think a lot of these officers would easily move away from their prison existence to some sort activity outside of the prison, into probation or something. I think they will not be personally be threatened by any reduction. Those who might be threatened would be higher staff, those

4 At his lecture on the day previous to the interview, Christie identified his stance on the use of prison as that of a minimalist. 
who make more money by being leaders of huge prisons or leaders of huge prison districts.

My experience nowadays is that the prison staff and their leaders very often define their roles as a protective one, vis-à-vis the prisoners. They are coming out and saying: "They are not bad people, but prisons are bad for them. Let us see to it that not too many people are being hurt by this system." So they warn against many of the moral panics in society.

Robert: I recently visited some prisons in Washington State. We were not even allowed to talk with the prisoners. The prison officials who were our guides told us that they protect the community; they did not seem to care about the prisoners.

Christie: It is very shocking to hear that. This confirms my anxiety vis-àvis the U.S. That system is completely out of control. There are features in the U.S. society that create anxiety, seen in the perspective of ordinary democratic ideas or humanistic ideas as to how we want our societies to develop.

Robert: The prison-industrial complex seems to be the strongest in the U.S.

Christie: Yes, the U.S. is my prime example.

Robert: So there you do have the interests of professionals

Christie: Of the prison staff? Yes, and apart from that, the U.S. system has such weakly-developed social services. There are no counter-professionals, as there are in many other systems. So for the U.S., I can only say that you do have vested interests.

Robert: When looking at self-reports and victim surveys, we can conclude that the people who end up in the retributive criminal justice system only constitute a very small percentage of all the crimes. This leads us to the following conclusion: a lot of people who are victimized are left in the cold. How can restorative justice overcome this problem?

Christie: I look at many of the processes of restorative justice as theatre. There might be, for example, eighty persons involved. That would be a very good performance. And it will spread to other people, that it is possible to think in these ways. John Braithwaite has often underlined this. He now runs his large experiment (the Re-itegrative Shaming Experiment, in Australia). 
Nearly a whole city has been involved in some sort of restorative justice. It is a very common topic socially - restorative justice-when they meet, during their dinners, et cetera, and this is interesting. It is as if the theatre came to town and everybody went to it. And maybe that theatre, that play, that joined interest can invoke some interests in social life. And maybe victimseven when it has not been made known to the authorities that they have been victimized - will draw their own conclusions while listening to this. They might think, "Oh, was that the case?" Restorative justice has the possibilities to develop as a sort of culture of restoration, that also spreads to others.

Robert: When talking about restorative justice as the first response to crime, how do you think it can prevent crime?

Christie: I think most of us would be scared to death by the idea that we should be the central person in a restorative justice process. If I had really hurt you and I should meet you, your relatives, your friends, and my friends and relatives would join me in that meeting, where I felt deep in my soul that I had done something terrible, at least to me that deterrent effect is considerably bigger than meeting before a judge, in an audience where I would have very few people who would know me. I don't think we can overestimate the unintended suffering and the courage it takes to meet under such circumstances. Maybe I exaggerate. I am a bit shy about exposing my bad side and I think this sort of exposure would be much harder than in a formalized court. So I think it would have no negative effect; it would have a very positive effect on general prevention. And we would also have a deeper insight: "Why did I do those terrible things?" This can be achieved better in these processes than in a court, where I should just try to defend myself. In the restorative process, it is just the opposite. I should open myself, to tell why I did it, and the more that is told the greater the chance that I will be forgiven. In the penal system, it is the opposite; the less I say, the better, because than they can take me for less.

Robert: Nowadays we hear a lot about victim empowerment. Do we have to draw a line in giving power to the victim and if so, where would we have to place the limits for victims?

Christie: Oh, yes. To me, the penal process is essential here. If the victim was unjust, if the process became too heavy, or if the offender felt it was 
too unjust, maybe his own friends turned against him, everybody just blamed him and blamed him and demanded and came with demands, perhaps the blame was greater than he accepted and then the demands were unrealisticif he wasn't able to convince that this was the case, he couldn't say, "I retreat from the process." We could also imagine-I mean, in the Canadian system, as far as I understand - a judge will have a very close connection to the process, and he might grow into the role of protecting the offender against the angry victim or against the whole surroundings.

In our system in Norway, where we have this system of conflict boards, the leader of the board will have to sign an agreement that the two parties also have to sign. And if the leader found that a young man who is seventeen has agreed to pay back, for example, one million dollars-which is completely unrealistic - he will not sign the contract, and the case would go back to an ordinary penal process. So it is so important to build in safety valves. I do not know all the literature on this, but I haven't seen much discussion on it among those who favour restorative justice. I have not seen many analyses of when it cannot be used. And I have not seen an analysis of how useful it may be for the restorative process to have the penal process. It is so important that we are aware of the fact that there are limits. And it is so important that we talk about these limits, and that it is not the crown and the prosecutors who are the only people taking up these matters. Because we have a use for their system, but we have to limit it.

And then there is another important thing: it is not clear who owns the conflict. That is an old theme for me; it goes back to my old article. ${ }^{5}$ But at that time, I hadn't thought of what is today obvious to me: that it is not clear that the prosecution owns the conflict. It is not clear that the crime is not necessarily a crime, and to allow the parties and the restoration process a place in the penal process on much more equal terms. Not only on equal terms, but to give a priority to the restoration process and that we give the prosecution what is "left over." That is a radical position. I think it is important not to let restorative justice be an alternative to punishment, but to let punishment be an alternative to restoration.

Robert: But that is one of the problems now. When restorative justice comes into the penal system, the penal system tends to use restorative justice processes as a way of diversion.

5 Dr. Christie refers here to his article "Conflicts as Property," published in The British Journal of Criminology, Vol. 17, No. 1, January, 1977. 
Christie: Yes, and I am very afraid of that. This has been the development in Norway. We have had our alternative mechanisms now already for ten years. I gave a speech last week for the people working in those mechanisms. I said there that I think the whole thing has stagnated. There are too few cases and there are too small cases and there is too little public discussion around these themes. And I have the feeling that here in Canada also, this whole idea of circle sentencing and restorative justice in all its forms was a good idea, but that it has not continued to grow. Some of the reasons are a lack of money for that part of the system. That is rather gruesome when you think of the costs of the prison system.

Robert: The penal system co-opted restorative justice. Give restorative justice the cases that are not important, so that the system does not have to spend too much money on it.

Christie: Or the penal system can send cases to restorative justice processes that wouldn't be handled in the penal system itself, a form of net-widening. Even though, when I read many of the restorative justice cases here, there are, of course, also some rather serious cases. That is a very encouraging thing.

Luc Robert studies criminological sciences at the Catholic University of Leuven in Belgium and is currently located at Simon Fraser University (British Columbia, Canada) on an exchange program. He can be contacted at the School of Criminology, Simon Fraser University, Burnaby, British Columbia V5A 1S6, Canada, or by e-mail at Robert_Luc99@hotmail.com. 